\title{
Protonated heterocyclic derivatives of cyclopropane and cyclopropanone: classical species, alternate sites, and ring fragmentation
}

\author{
Margarida S. Miranda, Darío J.R. Duarte, Joaquim C.G. Esteves da Silva, and Joel F. Liebman
}

\begin{abstract}
A computational study has been performed for protonated oxygen- or nitrogen-containing heterocyclic derivatives of cyclopropane and cyclopropanone. We have searched for the most stable conformations of the protonated species using density functional theory with the B3LYP functional and the 6-31G(2df,p) basis set. More accurate enthalpy values were obtained from G4 calculations. Proton affinities and gas-phase basicities were accordingly derived.
\end{abstract}

Key words: protonated cyclopropane and cyclopropanone derivatives, enthalpy, Gibbs energy, proton affinity, gas-phase basicity, QTAIM analysis.

Résumé : Nous avons réalisé une étude de modélisation sur des dérivés hétérocycliques protonés du cyclopropane ou de la cyclopropanone contenant un atome d'oxygène ou d'azote. Nous avons recherché les conformations les plus stables au moyen de la théorie de la fonctionnelle de la densité, en utilisant la fonctionnelle B3LYP et la base 6-31G(2df,p). La meilleure exactitude des valeurs d'enthalpie a été obtenue grâce aux calculs selon le modèle G4. De ces résultats ont été dérivées les affinités protoniques et les basicités en phase gazeuse. [Traduit par la Rédaction]

Mots-clés : dérivés protonés du cyclopropane et de la cyclopropanone, enthalpie, énergie de Gibbs, affinité protonique, basicité en phase gazeuse, théorie quantique des atomes dans les molécules.

\section{Introduction}

The structure and energetics of species with three-membered rings and the amide linkage have been actively studied by both the experimental and theoretical chemical communities. It is now acknowledged that measured enthalpy of formation data on species with three-membered rings of any type are simultaneously few in number ${ }^{1}$ and reliability is occasionally suspect. ${ }^{2}$ Likewise, measured proton affinities are almost totally absent for these species. Paralleling our recent publication, ${ }^{3}$ using cyclopropanone (1), aziridine (2), and oxirane (3) as archetypes, the assembled species for our current study are shown in Fig. 1: aziridine-2-one (also called $\alpha$-lactam, 4), oxirane-2-one (also called $\alpha$-acetolactone, 5), 1,2-diaziridine-3-one (6), 1,2-dioxirane-3-one (also called carbon trioxide, 7), 1,2-oxaziridine3-one (8), cyclopropane-1,2-dione (9), aziridine-2,3-dione (also called oximide, 10), and oxirane-2,3-dione (also called oxalic anhydride, 11); we recently also studied the associated enol tautomers such as the two rotamers of 2-hydroxycyclopropenol (9a) corresponding to cyclopropane-1,2-dione (9). ${ }^{3}$ An additional feature of interest is the site of protonation - nearly all of the neutral species have two or more such sites, e.g., the nitrogen and oxygen of aziridine-2-one (4). How can the proton affinity of each site be separately ascertained and understood? There is additionally also the possibility of ring rupturing and fragmentation upon protonation, e.g., is 2-hydroxyallyl cation not a plausible product of protonating cyclopropanone (1)? Calculational theory ameliorates the paucity of experimental infor- mation of energetics, structure, and any post-protonation reaction chemistry. The current study reports our computational findings for these and related neutral and protonated species where we have used the G4 method. ${ }^{4}$ Very good agreement is shown between the results from calculational theory and experimental proton affinity measurements where the latter is available for comparison. A QTAIM analysis ${ }^{5-7}$ was also performed with the electron density generated at the B3LYP/6-311++G(2d,2p) level of theory. The current investigation interrelates all of these studies and aids in their understanding and utility.

\section{Computational details}

In this study, we have used density functional theory with the B3LYP ${ }^{8,9}$ functional and the 6-31G(2df,p) basis set (level of theory used in the geometry optimization in the G4 method ${ }^{4}$ ) to search for the most stable conformations of the protonated derivatives of oxygen- and nitrogen-containing cyclopropanes and cyclopropanones. Vibrational frequency calculations were performed to characterize the stationary points found on the potential energy surface as minima or transition state structures. Calculations have also been carried out at the $\mathrm{G} 4^{4}$ level of theory for the most stable conformations of each species. All calculations were performed with Gaussian 09. ${ }^{10}$

A QTAIM analysis ${ }^{5-7}$ was carried using the AIMAll11 ${ }^{11}$ software, with the electron density generated at the B3LYP/6-311++G(2d,2p)

Received 13 January 2015. Accepted 19 February 2015.

M.S. Miranda* and J.C.G. Esteves da Silva. Centro de Investigação em Química, Departamento de Química e Bioquímica, Faculdade de Ciências da Universidade do Porto, Rua do Campo Alegre, s/n, P-4169-007 Porto, Portugal.

D.J.R. Duarte. Laboratorio de Estructura Molecular y Propiedades, Área de Química Física-Departamento de Química, Facultad de Ciencias Exactas y Naturales y Agrimensura, Universidad Nacional del Nordeste, Avenida Libertad 5460, (3400) Corrientes, Argentina.

J.F. Liebman. Department of Chemistry and Biochemistry, University of Maryland, Baltimore County, 1000 Hilltop Circle, Baltimore, MD 21250, USA.

Corresponding authors: Margarida S. Miranda (e-mail: msmirand@fc.up.pt) and Joel F. Liebman (e-mail: jliebman@umbc.edu).

*Present address: 3B's Research Group - Biomaterials, Biodegradables and Biomimetics, Department of Polymer Engineering, University of Minho, AvePark, Caldas das Taipas, Guimarães 4806-909, Portugal, ICVS/3B’s - PT Government Associate Laboratory, Braga/Guimarães 4806-909, Portugal. 
Fig. 1. Studied cyclopropane and cyclopropanone derivatives.

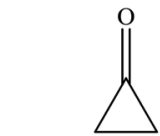

cyclopropanone (1)

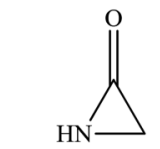

aziridine-2-one (4)

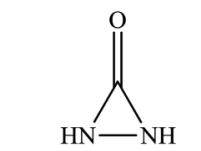

1,2-diaziridine-3-one (6)

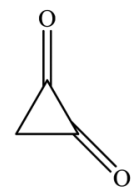

cyclopropane-1,2-dione (9)

level of theory. This analysis focuses on the properties at the bond critical points (denoted as $\mathbf{r}_{\mathrm{b}}$ ) of the electron density, $\rho(\mathbf{r})$, the Laplacian topology of the electronic density, $\nabla^{2} \rho(\mathbf{r})$, and selected atomic properties such as atomic populations, $N(\Omega)$, and atomic energy, $E(\boldsymbol{\Omega})$. The accuracy achieved in the calculation of the QTAIM atomic properties was checked through of sum of $N(\boldsymbol{\Omega})$ and $E(\Omega)$ on all atoms of the molecule. These values for each molecule reproduce total electron populations and electronic molecular energies, respectively. Another parameter corresponds to the values of the integrated Laplacian in each atomic basin, $L(\Omega)$. Ideally, this last parameter should be close to zero.

\section{Results and discussion}

\section{Structure and energetics of protonated cyclopropane and} cyclopropanone species

In previous work, we have searched for the most stable conformation of the corresponding neutral heterocyclic cyclopropane and cyclopropanones (see Fig. 1) at the B3LYP/6-31G(2df,p) level of theory. ${ }^{3}$ In this work, we have searched for the most stable conformations of oxygen and nitrogen protonated cyclopropane and cyclopropanone derivatives at the same level of theory.

In Table 1, we present the protonation site (see Fig. 2 for the atom numbering scheme), the description of the protonated species formed, symmetry point group used in calculations, the B3LYP/6-31G(2df,p) calculated absolute electronic energies (i.e., no zero-point energy and thermal corrections), and absolute enthalpies and Gibbs energies at $\mathrm{T}=298.15 \mathrm{~K}$.

The most stable conformations found for the protonated cyclopropane derivatives are shown in Fig. 3 where we include protonated cyclopropanone itself, as there is but one "hetero" atom on the three-membered ring.

From protonation of the oxygen atom of cyclopropanone, the closed-ring 1-hydroxycyclopropyl cation is formed. This cation was found to be more stable than the ring-opened 2-hydroxyallyl cation $\left(\mathrm{CH}_{2} \mathrm{C}^{+}(\mathrm{OH}) \mathrm{CH}_{2}\right)$ by $\Delta \mathrm{H}=2.9 \mathrm{~kJ} \mathrm{~mol}^{-1}$ at the B3LYP/6-31G(2df,p) level of theory. The barrier for going from the 1-hydroxycyclopropyl cation to the 2-hydroxyallyl cation is $\Delta E=4.4 \mathrm{~kJ} \mathrm{~mol}^{-1}$ (difference of B3LYP/6-31G(2df,p) electronic energies of transition state and 1-hydroxycyclopropyl cation). There is hesitancy in comparing these cations with the nominally related deprotonated neutrals, the highly strained but otherwise normal cyclopropanone, and the nonKekulé biradical (both singlet and triplet) oxyallyl.

$\mathrm{N}$-protonated aziridine presents a $\mathrm{C}_{2 \mathrm{v}}$ symmetry point group. The two hydrogen atoms bonded to the nitrogen atom are out of the plane of the ring, one on each side. This species is an altogether normal protonated secondary amine.

From protonation of the oxygen atom of oxirane, the closedring oxiranium cation is formed $\left(C_{s}\right.$ symmetry point group). The geometry around the oxygen atom was found to be pyramidal, with the hydrogen atom being $77^{\circ}$ out of the plane of the ring. The planar conformation obtained imposing a $C_{2 v}$ symmetry point group has one imaginary frequency (transition state structure). The calculated barrier to oxygen inversion is $64 \mathrm{~kJ} \mathrm{~mol}^{-1}$ (difference of B3LYP/6-31G(2df,p) electronic energies of transition state and pyramidal structure). Protonated oxirane is recognizable as a dialkyloxonium ion, and like the parent $\mathrm{H}_{3} \mathrm{O}^{+},{ }^{12}$ it is pyramidal. That aziridine has a much higher inversion barrier than ammonia provides isoelectronic reasoning support for the observation that protonated oxirane has a much higher inversion barrier than the hydronium ion.

The most stable conformations found for the protonated cyclopropanone derivatives are shown in Fig. 4. In the geometry optimization of the $\mathrm{N}$-protonated form of aziridine-2-one (4), the starting closed ring opens via $\mathrm{C}-\mathrm{N}$ bond cleavage and the formed species, nominally $\mathrm{H}_{2} \mathrm{NCH}_{2} \mathrm{CO}^{+}$, splits into two fragments, $\mathrm{CH}_{2} \mathrm{NH}_{2}{ }^{+}$ and $\mathrm{CO}$. This is in agreement with previous studies reported in the literature where a variety of $\mathrm{C}_{2} \mathrm{H}_{4} \mathrm{NO}^{+}$isomers were examined and it was concluded that N-protonated aziridine-2-one (4) is not an energy minimum on the potential energy surface and attempts to minimize it lead to dissociation products. ${ }^{13,14}$ Also, Lengyel et al. ${ }^{15}$ reported that strong acids with a negative $\mathrm{p} K_{\mathrm{a}}$ decarbonylate substituted aziridinones to give immonium salts (we also recognize C- and N-substituted $\mathrm{H}_{2} \mathrm{NCH}_{2} \mathrm{CO}^{+}$ions from mass spectrometric studies of peptides, in particular the so-called "b-ions", cf. Yalcin et al. ${ }^{16}$ and Harrison ${ }^{17}$ ). This is in agreement with previous studies reported for protonated aziridine.

From protonating the oxygen atom of 4 , two species can be formed, 40 Hanti and $\mathbf{4 O}_{4}$ syn (see Fig. 4). The 40 Hanti conformation was found to be more stable than $40 H s y n$ by about $6 \mathrm{~kJ} \mathrm{~mol}^{-1}$, in agreement with a computational study at HF/6-31G(d) reported in the literature. ${ }^{18}$ In both oxygen-protonated species, the hydrogen atom bonded to nitrogen is in the plane of the ring (sum of the bond angles at nitrogen is $360^{\circ}$ ), in contrast with what happens in 4 where the sum of the bond angles at nitrogen is $306^{\circ}$ (planarizing the nitrogen in amides (or nominally acylamines) such as aziridine-2-one is plausibly less energetically beneficial than in the corresponding oxygen-protonated ion as found in the cation). ${ }^{19,20}$ Morgan and Greenberg ${ }^{21}$ predicted the chemical shifts for the NMR of two nitrogen- and oxygen-protonated alkylated aziridine-2-ones within the context of the alternative protonated forms of strained amides.

In the case of oxirane-2-one (5), when the $\mathrm{O}_{2}$ oxygen atom of 5 is protonated, the ring opens and the $\mathrm{HOCH}_{2} \mathrm{CO}^{+}$species is formed (see Fig. 4, $5 \mathbf{O}_{2} \mathbf{H}$ ). Protonating the oxygen atom $\mathrm{O}_{4}$, two species can be formed, $\mathbf{5 O _ { 4 }}$ Hanti and $\mathbf{5} \mathbf{O}_{4} \mathbf{H s y n}$. The $\mathbf{5 O}_{\mathbf{4}} \mathbf{H s y n}$ conforma-

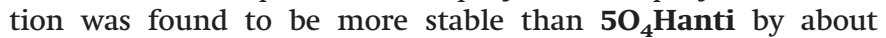
$4 \mathrm{~kJ} \mathrm{~mol}^{-1}$. Ruttink et al. ${ }^{22}$ used the $\mathrm{G} 2$ method to study the methoxycarbonyl cation and various isomers including $\mathbf{5 O}_{2} \mathbf{H}$, $\mathbf{5 O}_{\mathbf{4}} \mathbf{H s y n}$ and $\mathbf{5 O}_{\mathbf{4}} \mathrm{Hanti}$. The $\mathrm{G} 2$-predicted relative energetic stability of the three species, $\mathbf{5 O}_{2} \mathbf{H}>\mathbf{5 O}_{4} \mathbf{H s y n}>\mathbf{5 O}_{\mathbf{4}} \mathrm{Hanti}$, is in agreement with the one found in this study. It is plausible that an $\alpha-\mathrm{OH}$ offers a carbenium ion less stabilization than an $\alpha-\mathrm{NH}_{2}$ and so the $\left[\mathrm{HOCH}_{2}-\mathrm{CO}\right]^{+}$bond is stronger than in $\left[\mathrm{H}_{2} \mathrm{NCH}_{2}-\mathrm{CO}\right]^{+}$; it is not surprising that the former ion is more stable with regards to $\mathrm{C}-\mathrm{C}$ bond cleavage than the latter and indeed does not fragment 
Table 1. Protonation site, description of protonated species formed, symmetry point group and B3LYP/6-31 G(2df,p) absolute electronic energies and absolute enthalpies and Gibbs energies, at $T=298.15 \mathrm{~K}$, for the protonated cyclopropane and cyclopropanone derivatives.

\begin{tabular}{|c|c|c|c|c|c|c|}
\hline Protonated species & $\begin{array}{l}\text { Protonation } \\
\text { site }^{a}\end{array}$ & Description of species formed ${ }^{a}$ & $\begin{array}{l}\text { Symmetry } \\
\text { point group }\end{array}$ & $\begin{array}{l}E_{\text {B3LYP/6-31 G(2df,p) }} \\
\text { (hartree) }^{b}\end{array}$ & $\begin{array}{l}H_{\text {BзLYY/6-31 G(2df,p) }} \\
\text { (hartree) }^{b}\end{array}$ & $\begin{array}{l}G_{\mathrm{B} 3 \mathrm{LYP} / 6-31 \mathrm{G}(2 \mathrm{df}, \mathrm{p})} \\
{\text { (hartree })^{b}}\end{array}$ \\
\hline Cyclopropanone (1) & $\mathrm{O}$ & $\begin{array}{l}\text { Ring-closed (1-hydroxycyclopropyl } \\
\text { cation, 10H) }\end{array}$ & $\mathrm{C}_{\mathrm{s}}$ & -192.211171 & -192.132982 & -192.165537 \\
\hline Aziridine (2) & $\mathrm{N}$ & Ring-closed/2NH & $\mathrm{C}_{2 \mathrm{v}}$ & -134.298100 & -134.209356 & -134.237314 \\
\hline \multirow{2}{*}{ Oxirane (3) } & \multirow[t]{2}{*}{$\mathrm{O}$} & Ring-closed O pyramidal/3OH & $\mathrm{C}_{\mathrm{s}}$ & -154.110602 & -154.036068 & -154.064722 \\
\hline & & $\begin{array}{l}\text { Ring-closed O planar (transition } \\
\text { state) }\end{array}$ & $\mathrm{C}_{2 \mathrm{v}}$ & -154.086182 & & \\
\hline \multirow{2}{*}{ Aziridine-2-one (4) } & $\mathrm{O}_{4}$ & $\mathrm{H}$ syn to N/4OHsyn & $\mathrm{C}_{1}$ & -208.266757 & -208.198746 & -208.229953 \\
\hline & $\mathrm{N}$ & Splits into $\mathrm{CH}_{2} \mathrm{NH}_{2}{ }^{+}$and $\mathrm{CO}^{c}$ & & -208.305881 & -208.239423 & -208.287995 \\
\hline \multirow[t]{3}{*}{ Oxirane-2-one (5) } & $\mathrm{O}_{2}$ & Ring-opened $/ \mathbf{5 O}_{2} \mathrm{H}$ & $\mathrm{C}_{1}$ & -228.142451 & -228.087215 & -228.119270 \\
\hline & $\mathrm{O}_{4}$ & $\mathrm{H}$ syn to $\mathrm{O}_{2} / \mathbf{5 O _ { 4 }} \mathbf{H s y n}$ & $\mathrm{C}_{\mathrm{s}}$ & -228.122362 & -228.066849 & -228.097403 \\
\hline & $\mathrm{O}_{4}$ & $\mathrm{H}$ anti to $\mathrm{O}_{2} / \mathbf{5 O} \mathrm{O}_{4}$ Hanti & $\mathrm{C}_{\mathrm{s}}$ & -228.120893 & -228.065205 & -228.095701 \\
\hline \multirow[t]{2}{*}{ 1,2-Diaziridine-3-one (6) } & $\mathrm{N}$ & Ring-opened/6NH & $\mathrm{C}_{\mathrm{s}}^{\mathrm{s}}$ & -224.310728 & -224.253459 & -224.285071 \\
\hline & $\mathrm{O}$ & Ring-closed/6OH & $\mathrm{C}_{1}$ & -224.261169 & -224.205811 & -224.236367 \\
\hline & $\mathrm{O}_{4}$ & $\mathrm{H}$ anti to $\mathrm{N} / \mathbf{8 O}_{4}$ Hanti & $\mathrm{C}_{1}$ & -244.102963 & -244.060053 & -244.090404 \\
\hline & $\mathrm{O}_{4}$ & $\mathrm{H}$ syn to $\mathrm{N} / \mathbf{8 O}_{4} \mathbf{H s y n}$ & $\mathrm{C}_{1}$ & -244.101236 & -244.058278 & -244.088624 \\
\hline \multirow[t]{2}{*}{ Cyclopropane-1,2-dione (9) } & $\mathrm{O}$ & Ring-opened, $\mathrm{H}$ anti to $\mathrm{O} / \mathbf{9 O H}$ & $\mathrm{C}_{1}$ & -266.244792 & -266.183983 & -266.218186 \\
\hline & $\mathrm{O}$ & $\begin{array}{l}\text { Ring-closed, } \mathrm{H} \text { syn to O (transition } \\
\text { state) }\end{array}$ & $\mathrm{C}_{1}$ & -266.170345 & & \\
\hline \multirow[t]{3}{*}{ Syn-2-hydroxycyclopropenone (9a) } & $\mathrm{O}_{4}$ & $\mathrm{H}$ anti to $\mathrm{O}_{5} / \mathbf{9 a O} \mathrm{O}_{4} \mathrm{Hanti}$ & $\mathrm{C}_{1}$ & -266.237453 & -266.175060 & -266.207713 \\
\hline & $\mathrm{O}_{4}$ & $\mathrm{H}$ syn to $\mathrm{O}_{5} / \mathbf{9 a O _ { 4 }} \mathbf{H s y n}$ & $\mathrm{C}_{2 \mathrm{v}}$ & -266.234989 & -266.172689 & -266.204748 \\
\hline & $\mathrm{O}_{5}$ & $9 \mathrm{aO}_{5} \mathrm{H}$ & $\mathrm{C}_{1}$ & -266.151958 & -266.092333 & -266.127147 \\
\hline \multirow[t]{3}{*}{ Aziridine-2,3-dione (10) } & $\mathrm{O}$ & $\mathrm{H}$ syn to $\mathrm{N} / \mathbf{1 0 O}_{4} \mathrm{Hsyn}$ & $\mathrm{C}_{\mathrm{s}}$ & -282.280412 & -282.231233 & -282.264785 \\
\hline & $\mathrm{O}$ & $\mathrm{H}$ anti to $\mathrm{N} / \mathbf{1 0 O}_{4}$ Hanti & $\mathrm{C}_{\mathrm{s}}$ & -282.261834 & -282.212595 & -282.245549 \\
\hline & $\mathrm{N}$ & Splits into $\mathrm{NH}_{2} \mathrm{CO}^{+}$and $\mathrm{CO}^{c}$ & & -282.306436 & -282.259712 & -282.310196 \\
\hline \multirow[t]{2}{*}{ Oxirane-2,3-dione (11) } & $\mathrm{O}_{4}$ & $\mathrm{H}$ anti to $\mathrm{O}_{2} / \mathbf{1 1 O}_{4}$ Hanti & & -302.186615 & -302.151931 & -302.187702 \\
\hline & $\mathrm{O}_{4}$ & $\mathrm{H}$ syn to $\mathrm{O}_{2} / \mathbf{1 1 O H}$ & $\mathrm{C}_{\mathrm{s}}$ & -302.153953 & -302.116882 & -302.150657 \\
\hline
\end{tabular}

${ }^{a}$ See Fig. 2 for the numbering of the atoms.

${ }^{b} 1$ hartree $=2625.5 \mathrm{~kJ} \mathrm{~mol}^{-1}$.

cSummed values of $E(H$ or $G)$ for the two separate fragments.

Fig. 2. Atom numbering scheme of the protonated cyclopropanone derivatives.

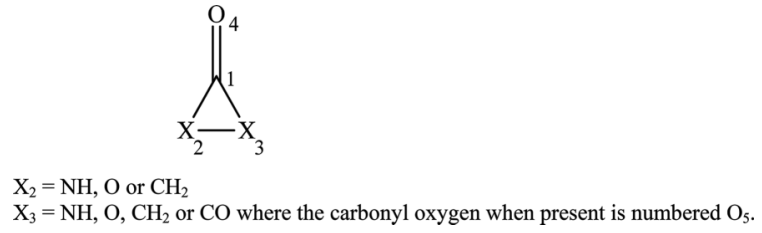

Fig. 3. B3LYP/6-31G(2df,p) optimized structure of protonated cyclopropanone, aziridine, and oxirane.

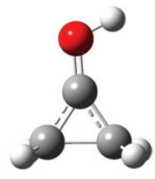

$10 \mathrm{H}$

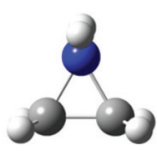

2NH

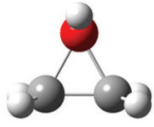

$30 \mathrm{H}$ at all. This is consistent with the relative rates of the acidcatalyzed decarbonylation of di- and triphenylacetic acids for which the differing stability of phenylated carbocations may be invoked. ${ }^{23}$ Relatedly, we expect the cationic nitrogen in $\mathrm{NH}_{2} \mathrm{NH}^{+}$ to be more electron deficient than the carbon in $\mathrm{NH}_{2} \mathrm{CH}_{2}{ }^{+}$, resulting in a stronger $\mathrm{N}-\mathrm{C}$ bond in $\mathrm{NH}_{2} \mathrm{NHCO}^{+}$than the $\mathrm{N}-\mathrm{C}$ bond in $\mathrm{H}_{2} \mathrm{NCH}_{2} \mathrm{CO}^{+}$. Indeed, protonating one of the nitrogen atoms of 1,2-diaziridine-3-one (6), the ring opens and the species $\mathrm{NH}_{2} \mathrm{NHCO}^{+}$ $(\mathbf{6 N H})$ is formed (see Fig. 4). When the oxygen atom is protonated, the ring remains closed and $\mathbf{6 0 H}$ is formed. In this species, the $\mathrm{O}-\mathrm{H}$ bond is in the plane of the ring; the $\mathrm{C}-\mathrm{N}$ and $\mathrm{C}-\mathrm{O}$ bonds are shorter than in $\mathbf{6}$. N-protonation of 6 is favored by $130 \mathrm{~kJ} \mathrm{~mol}-1$ over O-protonation.

When we protonate the oxygen atom $\mathrm{O}_{2}$ of 1,2-dioxirane-3-one

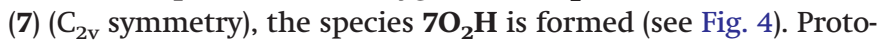
nating the oxygen atom $\mathrm{O}_{4}$ gives the $\mathbf{7 O}_{4} \mathbf{H}$ species where all atoms are in the same plane.

When the oxygen atom $\mathrm{O}_{3}$ of 1,2-oxaziridine-3-one (8) is protonated, the ring opens and the $\mathrm{OHNHCO}^{+}$species is formed $\left(\mathbf{8 O}_{3} \mathbf{H}\right)$ and when the nitrogen atom is protonated, the ring also opens and the $\mathbf{8 N H}$ species is formed (see Fig. 4). The ring remains closed when 8 is protonated in oxygen atom $\mathrm{O}_{4}$ and two conformations can be found, $\mathbf{8 O}_{4} \mathrm{Hanti}$ and $\mathbf{8 O}_{4} \mathrm{Hsyn}$, the first one being more stable than the second by $5 \mathrm{~kJ} \mathrm{~mol}^{-1}$.

The enol form of cyclopropane-1,2-dione (9), syn-2-hydroxycyclopropenone (9a), was previously found to be more stable than the keto form of 9. ${ }^{3}$ Protonating one oxygen atom of $\mathbf{9}$, the ring opens and the $\mathrm{CH}_{2} \mathrm{C}(\mathrm{OH}) \mathrm{CO}^{+}$cation is formed $(\mathbf{9 O H})$ (see Fig. 4). The structure with the hydrogen syn to the other oxygen and the ring closed has one imaginary frequency. We recognize this cation as the 2-hydroxy derivative of the stable acryloyl cation. ${ }^{24}$

From protonation of the oxygen $\mathrm{O}_{4}$ atom of $9 \mathrm{a}$, two conformers can be found, $9 \mathrm{aO}_{4} \mathrm{Hsyn}$ and $\mathbf{9 a O}_{4} \mathrm{Hanti}$. This last one was found 
Fig. 4. B3LYP/6-31G(2df,p) optimized structure of protonated cyclopropanone derivatives.

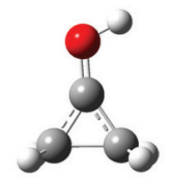

$10 \mathrm{H}$

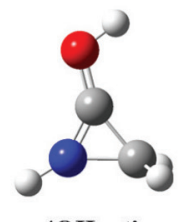

40Hanti

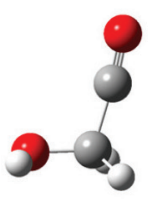

$5 \mathrm{O}_{2} \mathrm{H}$

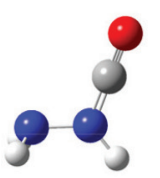

6NH

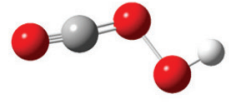

$7 \mathrm{O}_{2} \mathrm{H}$

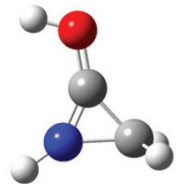

40Hsyn

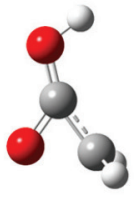

50 4 Hanti

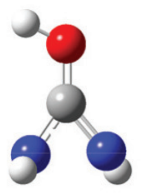

$6 \mathrm{OH}$

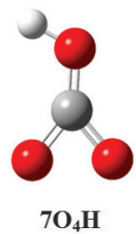

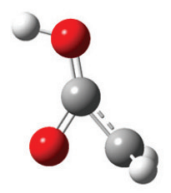

50.Hsyn

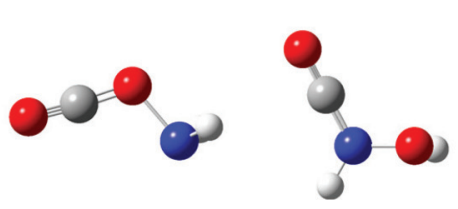

8NH

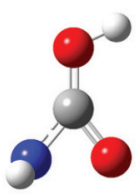

8O$_{4}$ Hanti

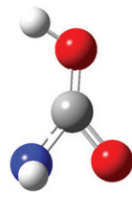

8O 4 Hsyn

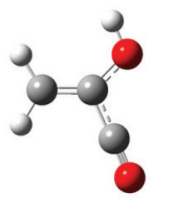

$90 \mathrm{H}$

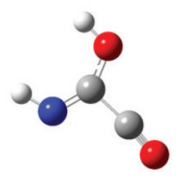

$10 O_{4}$ Hsyn

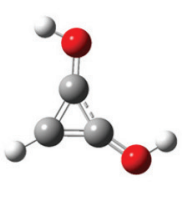

$9 \mathrm{aO}_{4} \mathrm{Hanti}$

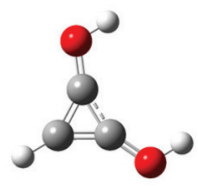

9aO 4 Hsyn

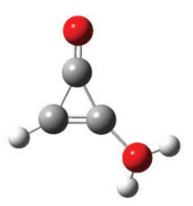

$9 \mathrm{aO}_{5} \mathrm{H}$

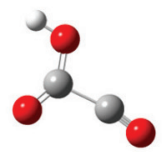

$110 H$

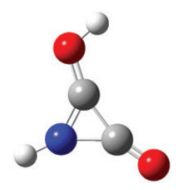

$10 \mathrm{O}_{4}$ Hanti

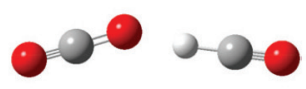

$110_{4}$ Hanti to be more stable than the first by only $6 \mathrm{~kJ} \mathrm{~mol}^{-1}$. Protonation of the $\mathrm{O}_{5}$ atom leads to the least stable isomer, $9 \mathrm{aO}_{5} \mathbf{H}$.

Protonation of the nitrogen atom of aziridine-2,3-dione (10) imposing a $\mathrm{C}_{2 \mathrm{v}}$ symmetry point group leads to a conformation with one imaginary frequency (transition state). Not imposing symmetry, the protonated species splits into two fragments, $\mathrm{NH}_{2} \mathrm{CO}^{+}$and CO. Considering the ion $\mathrm{NH}_{2} \mathrm{CO}^{+}$, this species may be recognized as protonated HNCO. The proton affinity of $\mathrm{HNCO}, 753 \mathrm{~kJ} \mathrm{~mol}^{-1}, 25$ (gas-phase basicity $\Delta G_{\text {basicity }}=718.8 \mathrm{~kJ} \mathrm{~mol}^{-125}$ ) is so much larger than that of CO (proton affinity (at carbon) $=594 \mathrm{~kJ} \mathrm{~mol}^{-125}$ and $\Delta G_{\text {basicity }}$ (at carbon) $=562.8 \mathrm{~kJ} \mathrm{~mol}^{-125}$ ) that it is not surprising that separated protonated $\mathrm{HNCO}$ and $\mathrm{CO}$ are seen upon nitrogen protonation of species 10 . That the dipole moment of $\mathrm{CO}$ is so close to zero also makes any complex of $\mathrm{NH}_{2} \mathrm{CO}^{+}$and $\mathrm{CO}$ but very weakly bound.

When the oxygen atom is protonated with the $\mathrm{O}-\mathrm{H}$ bond syn to nitrogen, the ring opens and the $\mathrm{C}(\mathrm{OH})(\mathrm{NH}) \mathrm{CO}^{+}$species is formed (see Fig. 4) (100 $\left.\mathbf{1 0}_{\mathbf{H}} \mathbf{H s y n}\right)$. Protonating the oxygen atom with the $\mathrm{O}-\mathrm{H}$ anti to nitrogen, the ring remains closed $\left(\mathbf{1 0 O}_{\mathbf{4}}\right.$ Hanti).

In the case of oxirane-2,3-dione (11), protonating $\mathrm{O}_{4}$ with the hydrogen atom in a syn conformation to $\mathrm{O}_{2}$ or protonating $\mathrm{O}_{2}$ leads to the same conformer, $\mathbf{1 1 O H}$ (see Fig. 4). Protonating the $\mathrm{O}_{2}$ atom imposing a $\mathrm{C}_{2 \mathrm{v}}$ symmetry leads to a conformer with one imaginary frequency. Protonating $\mathrm{O}_{4}$ with the hydrogen atom with an anti conformation to $\mathrm{O}_{2}$, the closed ring opens and the formed species $\mathrm{CO}(\mathrm{OH}) \mathrm{CO}^{+}$(it is $\mathbf{1 1 O H}$ but with the $\mathrm{OH}$ in the other direction) and the complex $\mathbf{1 1 O}_{\mathbf{4}}$ Hanti is formed (see Fig. 4). The proton affinity of $\mathrm{CO}$ is higher than that of $\mathrm{CO}_{2}$ (proton affinity $=540.5 \mathrm{~kJ} \mathrm{~mol}^{-125}$ and $\Delta G_{\text {basicity }}=515.8 \mathrm{~kJ} \mathrm{~mol}^{-125}$ ) and that is why the $\mathrm{H}^{+}$moves towards $\mathrm{CO}$. The enthalpy of the reaction $\mathrm{HCO}^{+}+\mathrm{CO}_{2} \rightarrow$ complex $\mathbf{1 1 O}_{4} \mathrm{Hanti}$ is $-59.3 \mathrm{~kJ} \mathrm{~mol}^{-1}$, which is in good agreement the experimental clustering energy for these species, $-52.7 \mathrm{~kJ} \mathrm{~mol}^{-1}$, from Hiraoka et al. ${ }^{26}$

\section{Calculated proton affinities and gas-phase basicities}

Calculated G4 absolute enthalpies and Gibbs energies, at T = $298.15 \mathrm{~K}$, calculated only for the most stable conformations found for the cyclopropane and cyclopropanone derivatives and their protonated species are given in Table S1 and Table S2, respectively, of the supplementary data (see Supplementary material section). From these calculation, we were able to calculate proton affinities and gas-phase basicities. which are presented in Table 2. In this table, we also provide existing experimental values for comparison, taken from the classic review of Hunter and Lias. ${ }^{25}$ There are experimental data for the cyclopropane derivatives, aziridine (2) and oxirane (3), and there are no experimental data 
Table 2. Protonation site and G4 calculated gas-phase proton affinities (PA) and basicities ( $\left.\Delta G_{\text {basicity }}\right)$, at $T=298.15 \mathrm{~K}$, for the cyclopropane and cyclopropanone derivatives.

\begin{tabular}{|c|c|c|c|c|c|}
\hline \multirow[b]{2}{*}{ Molecule } & \multirow[b]{2}{*}{$\begin{array}{l}\text { Protonation } \\
\text { site }^{a}\end{array}$} & \multicolumn{2}{|c|}{$\begin{array}{l}\mathrm{PA} \\
\left(\mathrm{kJ} \mathrm{mol}{ }^{-1}\right)\end{array}$} & \multicolumn{2}{|c|}{$\begin{array}{l}\Delta G_{\text {basicity }} \\
\left(\mathrm{kJ} \mathrm{mol}^{-1}\right)\end{array}$} \\
\hline & & G4 & Exp. $^{25}$ & G4 & $\operatorname{Exp}^{25}$ \\
\hline Cyclopropanone (1) & $\mathrm{O}$ & 772.4 & & 746.3 & \\
\hline Aziridine (2) & $\mathrm{N}$ & 908.6 & 905.5 & 875.1 & 872.5 \\
\hline Oxirane (3) & $\mathrm{O}$ & 769.0 & 774.2 & 737.8 & 745.3 \\
\hline \multirow[t]{2}{*}{ Aziridine-2-one (4) } & $\mathrm{O}_{4}($ anti to $\mathrm{N})$ & 802.5 & & 772.4 & \\
\hline & $\mathrm{O}_{4}(\operatorname{syn}$ to $\mathrm{N})$ & 797.5 & & 767.5 & \\
\hline \multirow[t]{3}{*}{ Oxirane-2-one (5) } & $\mathrm{O}_{2}$ & 805.0 & & 778.2 & \\
\hline & $\mathrm{O}_{4}\left(\operatorname{syn}\right.$ to $\left.\mathrm{O}_{2}\right)$ & 735.4 & & 704.6 & \\
\hline & $\mathrm{O}_{4}\left(\right.$ anti to $\left.\mathrm{O}_{2}\right)$ & 731.2 & & 700.2 & \\
\hline \multirow[t]{2}{*}{ 1,2-Diaziridine-3-one (6) } & $\mathrm{N}$ & 851.5 & & 825.0 & \\
\hline & $\mathrm{O}$ & 726.2 & & 696.9 & \\
\hline \multirow[t]{2}{*}{ 1,2-Dioxirane-3-one (7) } & $\mathrm{O}_{2}$ & 634.1 & & 610.7 & \\
\hline & $\mathrm{O}_{4}$ & 621.7 & & 592.3 & \\
\hline \multirow[t]{4}{*}{ 1,2-Oxaziridine-3-one (8) } & $\mathrm{O}_{3}$ & 759.3 & & 731.0 & \\
\hline & $\mathrm{N}$ & 738.2 & & 711.1 & \\
\hline & $\mathrm{O}_{4}($ anti to $\mathrm{N})$ & 682.9 & & 651.9 & \\
\hline & $\mathrm{O}_{4}(\operatorname{syn}$ to $\mathrm{N})$ & 678.4 & & 647.7 & \\
\hline Cyclopropane-1,2-dione (9) & $\mathrm{O}$ & 922.0 & & 887.4 & \\
\hline Syn-2-hydroxycyclopropenone & $\mathrm{O}_{4}$ (anti to $\left.\mathrm{O}_{5}\right)$ & 847.6 & & 815.2 & \\
\hline \multirow{2}{*}{ (9a) } & $\mathrm{O}_{4}\left(\operatorname{syn}\right.$ to $\left.\mathrm{O}_{5}\right)$ & 842.0 & & 808.1 & \\
\hline & $\mathrm{O}_{5}$ & 636.1 & & 609.5 & \\
\hline \multirow[t]{2}{*}{ Aziridine-2,3-dione (10) } & $\mathrm{O}(\operatorname{syn}$ to $\mathrm{N})$ & 800.9 & & 770.9 & \\
\hline & $\mathrm{O}$ (anti to $\mathrm{N})$ & 732.9 & & 701.3 & \\
\hline \multirow[t]{3}{*}{ Oxirane-2,3-dione (11) } & $\mathrm{O}_{4}$ (anti to $\mathrm{O}_{2}$ ) & 886.5 & & 863.8 & \\
\hline & $\mathrm{O}_{4}\left(\operatorname{syn}\right.$ to $\left.\mathrm{O}_{2}\right)$ & 789.1 & & 761.2 & \\
\hline & $\mathrm{O}_{2}$ & 789.1 & & 761.2 & \\
\hline
\end{tabular}

${ }^{a}$ See Fig. 2 for the numbering of the atoms.

regarding the cyclopropanone derivatives. The $\mathrm{G} 4$ estimates are in very good agreement with the existent experimental data.

\section{QTAIM analysis}

The topological analysis of the electron density, $\rho(\mathbf{r})$, and its Laplacian function, $\nabla^{2} \rho(\mathbf{r})$, has been made for the protonated cyclopropane and cyclopropanone derivatives. The results are reported in Tables 3 and 4 and Fig. 5.

In all cases when the $\mathrm{O}_{4}$ atom is protonated (see Table 3), the $\mathrm{C}_{1}-\mathrm{O}_{4}$ interatomic distances are longer than a conventional $\mathrm{C}=\mathrm{O}$ double bond (except in the $\mathbf{1 1 0}_{\mathbf{4}}$ Hanti species) and slightly shorter than protonated acetone. In these cases, the $\mathrm{C}_{1}-\mathrm{O}_{4}$ interatomic distances range from $1.242 \AA$ (in $\mathbf{7 0} \mathbf{O}_{4} \mathbf{H}$ species) to $1.334 \AA$ (in 90H species), while the $\mathrm{C}-\mathrm{O}$ interatomic distances are 1.209 and $1.379 \AA$ in acetone and protonated acetone, respectively. Topological parameters enable us to characterize the double bond. In all protonated species studied here, $\rho\left(\mathbf{r}_{\mathrm{b}}\right)$ and, in most cases, also $\varepsilon$ at the bond critical point $\mathrm{C}_{1}-\mathrm{O}_{4}$ (see Table 3 ) are lower than the values found in the $\mathrm{C}=\mathrm{O}$ double covalent bonds (i.e., $\rho\left(\mathbf{r}_{\mathrm{b}}\right)=$ 0.4219 au and $\varepsilon=0.08$ in acetone). Moreover, the bond order $n$ of the $\mathrm{C}-\mathrm{O}$ bond has also been examined within the framework of QTAIM $^{5-7}$ with the expression $\left.n=\exp \left[A \rho\left(\mathbf{r}_{\mathrm{b}}\right)-B\right)\right]$, where $A=5.1151$ and $B=1.4616$. The bond order $n$ denotes a decrease of the double bond character of the $\mathrm{C}_{1}-\mathrm{O}_{4}$ interatomic interaction. These results clearly show that protonation on $\mathrm{O}_{4}$ lessens the bond order and thereby weakens the $\mathrm{C}_{1}-\mathrm{O}_{4}$ bond as befits the greater contribution of the resonance structure $>\mathrm{C}^{+}-\mathrm{OH}$ to the protonated species than $>\mathrm{C}^{+}-\mathrm{O}^{-}$to the parent carbonyl species.

On the other hand, the $\mathrm{C}_{1}-\mathrm{O}_{4}$ bonds in $\mathbf{5 O}_{2} \mathbf{H}, \mathbf{6 N H}, \mathbf{7 O}_{2} \mathbf{H}, \mathbf{8 N H}$, and $\mathbf{8 O}_{3} \mathrm{H}$ species and the $\mathrm{C}_{3}-\mathrm{O}_{5}$ bonds in $\mathbf{9 0 H}, \mathbf{1 0 O}_{4} \mathrm{Hsyn}$, $10 \mathrm{O}_{4}$ Hanti, $110 \mathrm{H}$, and $11 \mathrm{O}_{4}$ Hanti species are similar to the $\mathrm{C} \equiv \mathrm{O}$ triple bond in diatomic $\mathrm{CO}$. The $\mathrm{C}-\mathrm{O}$ interatomic distances are around $1.1 \AA$ and $\rho\left(\mathbf{r}_{\mathrm{b}}\right)$ values are around 0.50 au. That is, these
Table 3. Interatomic distances and selected local topological properties of the electronic charge density distribution calculated at the position of the bond critical points of selected bond paths.

\begin{tabular}{|c|c|c|c|c|c|c|}
\hline Species & Bond & $d$ & $\rho\left(\mathbf{r}_{\mathrm{b}}\right)$ & $\nabla^{2} \rho\left(\mathbf{r}_{\mathrm{b}}\right)$ & $\varepsilon$ & $n$ \\
\hline \multirow[t]{2}{*}{ 40Hanti } & $\mathrm{C}_{1}-\mathrm{O}_{4}$ & 1.273 & 0.3585 & -0.6344 & 0.03 & 1.45 \\
\hline & $\mathrm{O}_{4}-\mathrm{H}$ & 0.974 & 0.3532 & -2.7631 & 0.01 & \\
\hline \multirow[t]{2}{*}{ 40Hsyn } & $\mathrm{C}_{1}-\mathrm{O}_{4}$ & 1.271 & 0.3600 & -0.6329 & 0.04 & 1.46 \\
\hline & $\mathrm{O}_{4}-\mathrm{H}$ & 0.976 & 0.3509 & -2.7242 & 0.01 & \\
\hline \multirow[t]{2}{*}{$5 \mathrm{O}_{2} \mathrm{H}$} & $\mathrm{C}_{1}-\mathrm{O}_{4}$ & 1.116 & 0.5124 & 0.5105 & 0.00 & 3.19 \\
\hline & $\mathrm{O}_{2}-\mathrm{H}$ & 0.969 & 0.3634 & -2.7605 & 0.02 & \\
\hline \multirow[t]{2}{*}{$50_{4}$ Hsyn } & $\mathrm{C}_{1}-\mathrm{O}_{4}$ & 1.257 & 0.3742 & -0.6432 & 0.06 & 1.57 \\
\hline & $\mathrm{O}_{4}-\mathrm{H}$ & 0.982 & 0.3427 & -2.6902 & 0.01 & \\
\hline \multirow[t]{2}{*}{$5 \mathrm{O}_{4}$ Hanti } & $\mathrm{C}_{1}-\mathrm{O}_{4}$ & 1.259 & 0.3725 & -0.6381 & 0.06 & 1.56 \\
\hline & $\mathrm{O}_{4}-\mathrm{H}$ & 0.977 & 0.3475 & -2.7433 & 0.01 & \\
\hline \multirow[t]{2}{*}{$6 \mathrm{NH}$} & $\mathrm{C}_{1}-\mathrm{O}_{4}$ & 1.132 & 0.4926 & 0.2875 & 0.04 & 2.88 \\
\hline & $\mathrm{N}_{2}-\mathrm{H}$ & 1.017 & 0.3444 & -1.8195 & 0.05 & \\
\hline \multirow[t]{2}{*}{$60 \mathrm{H}$} & $\mathrm{C}_{1}-\mathrm{O}_{4}$ & 1.257 & 0.3737 & -0.6450 & 0.09 & 1.57 \\
\hline & $\mathrm{O}_{4}-\mathrm{H}$ & 0.979 & 0.3455 & -2.7214 & 0.01 & \\
\hline \multirow[t]{2}{*}{$7 \mathrm{O}_{2} \mathrm{H}$} & $\mathrm{C}_{1}-\mathrm{O}_{4}$ & 1.127 & 0.4961 & 0.3799 & 0.03 & 2.93 \\
\hline & $\mathrm{O}_{2}-\mathrm{H}$ & 0.985 & 0.3500 & -2.7472 & 0.04 & \\
\hline \multirow[t]{2}{*}{$7 \mathrm{O}_{4} \mathrm{H}$} & $\mathrm{C}_{1}-\mathrm{O}_{4}$ & 1.242 & 0.3922 & -0.7598 & 0.13 & 1.72 \\
\hline & $\mathrm{O}_{4}-\mathrm{H}$ & 0.984 & 0.3345 & -2.6778 & 0.01 & \\
\hline \multirow[t]{2}{*}{$8 \mathrm{NH}$} & $\mathrm{C}_{1}-\mathrm{O}_{4}$ & 1.129 & 0.4948 & 0.3014 & 0.02 & 2.91 \\
\hline & $\mathrm{N}_{2}-\mathrm{H}$ & 1.029 & 0.3403 & -1.8513 & 0.05 & \\
\hline \multirow[t]{2}{*}{$8 \mathrm{O}_{3} \mathrm{H}$} & $\mathrm{C}_{1}-\mathrm{O}_{4}$ & 1.132 & 0.4922 & 0.3193 & 0.04 & 2.87 \\
\hline & $\mathrm{O}_{3}-\mathrm{H}$ & 0.977 & 0.3584 & -2.7523 & 0.04 & \\
\hline \multirow[t]{2}{*}{$80_{4}$ Hanti } & $\mathrm{C}_{1}-\mathrm{O}_{4}$ & 1.251 & 0.3821 & -0.7198 & 0.11 & 1.64 \\
\hline & $\mathrm{O}_{4}-\mathrm{H}$ & 0.982 & 0.3396 & -2.6899 & 0.01 & \\
\hline \multirow[t]{2}{*}{$80_{4}$ Hsyn } & $\mathrm{C}_{1}-\mathrm{O}_{4}$ & 1.251 & 0.3814 & -0.7115 & 0.10 & 1.63 \\
\hline & $\mathrm{O}_{4}-\mathrm{H}$ & 0.980 & 0.3419 & -2.7138 & 0.01 & \\
\hline \multirow[t]{3}{*}{$90 \mathrm{H}$} & $\mathrm{C}_{1}-\mathrm{O}_{4}$ & 1.334 & 0.3209 & -0.8544 & 0.16 & 1.20 \\
\hline & $\mathrm{O}_{4}-\mathrm{H}$ & 0.969 & 0.3594 & -2.7620 & 0.02 & \\
\hline & $\mathrm{C}_{3}-\mathrm{O}_{5}$ & 1.123 & 0.5041 & 0.4292 & 0.01 & 3.06 \\
\hline \multirow[t]{2}{*}{$9 \mathrm{aO}_{4}$ Hanti } & $\mathrm{C}_{1}-\mathrm{O}_{4}$ & 1.281 & 0.3501 & -0.6244 & 0.01 & 1.39 \\
\hline & $\mathrm{O}_{4}-\mathrm{H}$ & 0.973 & 0.3557 & -2.7599 & 0.01 & \\
\hline \multirow[t]{2}{*}{$9 \mathrm{aO}_{4} \mathrm{Hsyn}$} & $\mathrm{C}_{1}-\mathrm{O}_{4}$ & 1.284 & 0.3480 & -0.6238 & 0.01 & 1.38 \\
\hline & $\mathrm{O}_{4}-\mathrm{H}$ & 0.972 & 0.3571 & -2.7649 & 0.01 & \\
\hline \multirow[t]{2}{*}{$9 \mathrm{aO}_{5} \mathrm{H}$} & $\mathrm{C}_{1}-\mathrm{O}_{4}$ & 1.166 & 0.4580 & -0.1241 & 0.06 & 2.41 \\
\hline & $\mathrm{O}_{5}-\mathrm{H}$ & 0.982 & 0.3459 & -2.7719 & 0.02 & \\
\hline \multirow[t]{3}{*}{$10 \mathrm{O}_{4} \mathrm{Hsyn}$} & $\mathrm{C}_{1}-\mathrm{O}_{4}$ & 1.314 & 0.3359 & -0.8606 & 0.17 & 1.29 \\
\hline & $\mathrm{O}_{4}-\mathrm{H}$ & 0.973 & 0.3533 & -2.7383 & 0.01 & \\
\hline & $\mathrm{C}_{3}-\mathrm{O}_{5}$ & 1.117 & 0.5113 & 0.5227 & 0.00 & 3.17 \\
\hline \multirow[t]{3}{*}{$10 O_{4}$ Hanti } & $\mathrm{C}_{1}-\mathrm{O}_{4}$ & 1.266 & 0.3648 & -0.6288 & 0.04 & 1.50 \\
\hline & $\mathrm{O}_{4}-\mathrm{H}$ & 0.977 & 0.3476 & -2.7417 & 0.01 & \\
\hline & $\mathrm{C}_{3}-\mathrm{O}_{5}$ & 1.160 & 0.4652 & -0.0692 & 0.11 & 2.50 \\
\hline \multirow[t]{3}{*}{$110 H$} & $\mathrm{C}_{1}-\mathrm{O}_{4}$ & 1.291 & 0.3564 & -0.8918 & 0.17 & 1.44 \\
\hline & $\mathrm{O}_{4}-\mathrm{H}$ & 0.980 & 0.3445 & -2.7025 & 0.01 & \\
\hline & $\mathrm{C}_{3}-\mathrm{O}_{5}$ & 1.114 & 0.5145 & 0.5760 & 0.00 & 3.22 \\
\hline \multirow[t]{3}{*}{$110_{4}$ Hanti } & $\mathrm{C}_{1}-\mathrm{O}_{4}$ & 1.181 & 0.4382 & -0.3700 & 0.01 & 2.18 \\
\hline & $\mathrm{O}_{4} \cdots \mathrm{H}$ & 1.470 & 0.0724 & 0.1468 & 0.00 & \\
\hline & $\mathrm{C}_{3}-\mathrm{O}_{5}$ & 1.110 & 0.5220 & 0.5623 & 0.00 & 3.35 \\
\hline
\end{tabular}

Note: See Fig. 2 for the numbering of the atoms. $d$, interatomic distances; $\rho\left(\mathbf{r}_{\mathrm{b}}\right)$, electron density; $\nabla^{2} \rho\left(\mathbf{r}_{\mathrm{b}}\right)$, Laplacian of the electron density; $\varepsilon$, ellipticity of the electron density; $n$, bond order. Distances in angstroms, $\rho\left(\mathbf{r}_{\mathrm{b}}\right)$ and $\nabla^{2} \rho\left(\mathbf{r}_{\mathrm{b}}\right)$ in atomic units, and $\varepsilon$ and $n$ dimensionless.

values are nearly the same as in CO (1.113 $\AA$ and $0.5001 \mathrm{au})$ and in protonated CO, i.e., $\mathrm{HCO}^{+}(1.107 \AA$ and $0.5153 \mathrm{au})$.

In all cases when oxygen/nitrogen atoms are protonated, the $\mathrm{O}-\mathrm{H} / \mathrm{N}-\mathrm{H}$ interatomic distances are on the same order of magnitude of that of a conventional $\mathrm{O}-\mathrm{H} / \mathrm{N}-\mathrm{H}$ bond (about 0.95 and $1.02 \AA$ A, respectively). Topological parameters reveal (see Table 3 ) that $\mathrm{O}-\mathrm{H} / \mathrm{N}-\mathrm{H}$ interactions are within the shared-shell regime $\left(\rho\left(\mathbf{r}_{\mathrm{b}}\right)\right.$ relatively high and $\left.\nabla^{2} \rho\left(\mathbf{r}_{\mathrm{b}}\right)<0\right)$. In other words, according to QTAIM, an $\mathrm{O}-\mathrm{H} / \mathrm{N}-\mathrm{H}$ covalent bond is formed as a result of the protonation of an oxygen/nitrogen atom.

The $L(\mathbf{r})=-1 / 4 \nabla^{2} \rho(\mathbf{r})$ function shows the regions of the space where $\rho(\mathbf{r})$ is locally concentrated $(L(\mathbf{r})>0)$ or depleted $(L(\mathbf{r})<0){ }^{5-7}$ In a previous work, we have used this function to show that triplet 


\section{Pagination not final (cite DOI) / Pagination provisoire (citer le DOI)}

Table 4. Total electronic energy of molecule, atomic energy, and atomic electronic population on protonation site for the protonated cyclopropanone species and cyclopropanone derivatives isolated (in parentheses).

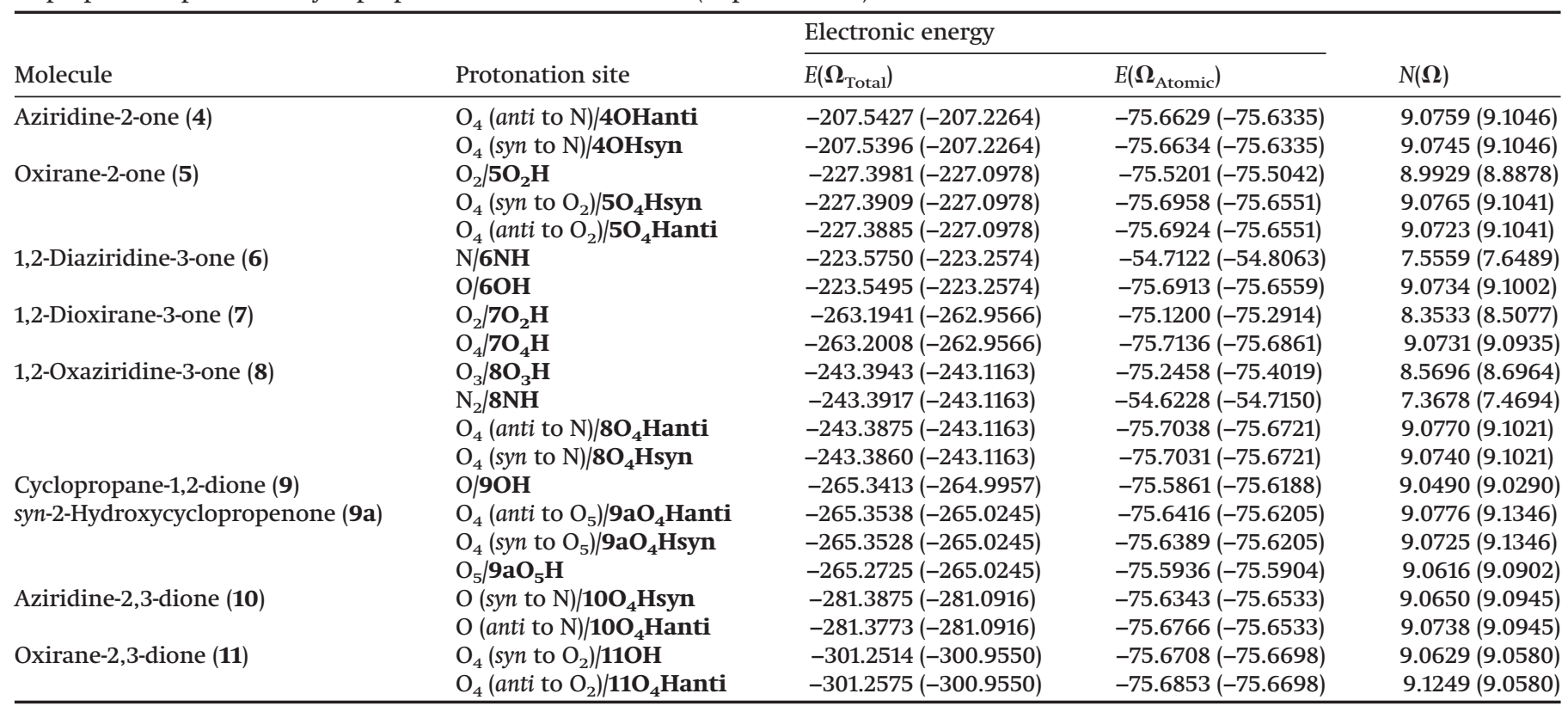

Note: See Fig. 2 for the numbering of the atoms; all values in atomic units.

Fig. 5. Molecular graph and nonbonded maxima of the $L(\mathbf{r})$ function (critical points $(3,-3)$ in $L(\mathbf{r})$ ) for the 1,2-oxaziridine-3-one molecule. The red dots indicate the preferred protonation sites. Color in online version only.

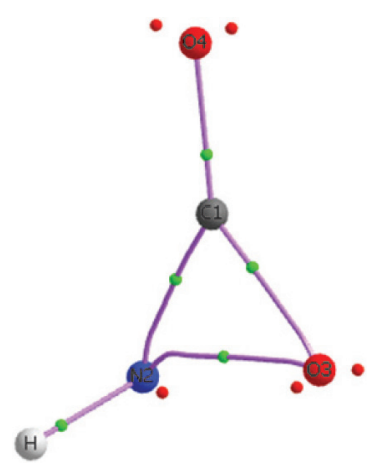

vinyl nitrene has lone pairs available to interact electrostatically with a Lewis acid to form a Lewis adduct. ${ }^{27}$ With this in mind, we wanted to check if the preferred protonation sites can be predicted through the localization of the nonbonded maxima of the $L(\mathbf{r})$ function (critical points $(3,-3)$ in $L(\mathbf{r}))$. The critical points $(3,-3)$ correspond in number and position to the electron pairs defined by the Lewis and VSEPR model and correspond to zones where an electrophilic attack can occur. ${ }^{28}$ Figure 5 shows the critical points $(3,-3)$ in $L(\mathbf{r})$ and molecular graph for 1,2-oxaziridine-3-one (5). In this figure, it can clearly be observed the preferred protonation sites through the local charge concentration (lump - critical point $(3,-3)$ in $L(\mathbf{r}))$ in the valence shell charge concentration of the nitrogen and oxygen atoms.

The valence shell charge concentration of $\mathrm{O}_{4}$ exhibits two nonbonded maxima (see the red dots in Fig. 5). The endocyclic oxygen atom has two sites of protonation, while the endocyclic nitrogen atom has a single site of protonation. These results agree with species formed upon protonation. That is, when the $\mathrm{O}_{4}$ is protonated, $\mathbf{8 O}_{4} \mathrm{Hanti}$ and $\mathbf{8 O}_{4} \mathrm{Hsyn}$ species are formed and when the $\mathrm{O}_{3}$ is protonated, $\mathbf{8 O}_{3} \mathbf{H}$ species is formed, while when the $\mathrm{N}_{2}$ is protonated, $\mathbf{8 N H}$ species is formed. Similar situations are observed in all other cyclopropanone derivatives.
The integration of electron density on the atomic basins of the protonation site provides a useful tool for analyzing charge redistribution that occurs as a result of protonation. Table 4 reports the total electronic energy of the molecule, atomic electronic energy, and electronic population.

In all cases, it is observed that the total electronic energy of the protonated cyclopropanone derivatives is greater in magnitude than that of the isolated neutral molecule. That is to say, the protonated cyclopropanone derivatives are more stable than the nonprotonated species. Moreover, in most cases, the heteroatom being protonated is stabilized (except in $\mathbf{6 N H}, \mathbf{7 O}_{\mathbf{2}} \mathbf{H}, \mathbf{8 N H}, \mathbf{8 O _ { 3 }} \mathbf{H}$, $\mathbf{9 O H}$, and $10 \mathrm{O}_{4} \mathbf{H s y n}$ species).

The protonation of the molecules causes a decrease of the electronic population of the protonated atom (see Table 4), except when the $\mathrm{O}_{2}$ atom of 5 , the oxygen atom of $\mathbf{9}$, and the $\mathrm{O}_{4}$ (syn and anti to $\mathrm{O}_{2}$ ) atom of $\mathbf{1 1}$ are protonated.

The QTAIM results suggest. (1) Protonation on $\mathrm{O}_{4}$ weakens the $\mathrm{C}_{1}-\mathrm{O}_{4}$ bond. Moreover, the $\mathrm{C}_{1}-\mathrm{O}_{4}$ bonds in $\mathbf{5 O}_{2} \mathbf{H}, \mathbf{6 N H}, \mathbf{7 O _ { 2 }} \mathbf{H}$, $\mathbf{8 N H}$, and $\mathbf{8 O}_{3} \mathbf{H}$ species and the $\mathrm{C}_{3}-\mathrm{O}_{5}$ bond in $\mathbf{9 O H}, \mathbf{1 0 O}_{4} \mathbf{H s y n}$, $\mathbf{1 0 O}_{\mathbf{4}}$ Hanti, $\mathbf{1 1 O H}$, and $\mathbf{1 1 O}_{\mathbf{4}} \mathrm{Hanti}$ species are similar to the $\mathrm{C} \equiv \mathrm{O}$ triple bond in diatomic CO. (2) When a nitrogen or oxygen atom is protonated, a N-H/O-H covalent bond is formed. In addition, the cyclopropanone derivative species are less stable than their protonated counterparts. (3) The topological analysis of the $L(\mathbf{r})$ function reveals that the localization of the nonbonded maxima (critical points $(3,-3)$ in $L(\mathbf{r})$ ) correspond in number and position to the electron pairs defined by the Lewis structures and VSEPR model and are the preferred protonation sites.

\section{Supplementary material}

Supplementary material is available with the article through the journal Web site at http://nrcresearchpress.com/doi/suppl/10.1139/ cjc-2015-0029.

\section{Acknowledgement}

D.J.R. Duarte gratefully acknowledges the Secretaría de Ciencia y Tecnología de la Universidad Nacional del Nordeste (SECYT UNNE). 


\section{Pagination not final (cite DOI) / Pagination provisoire (citer le DOI)}

\section{References}

(1) Liebman, J. F.; Greenberg, A. Chem. Rev. 1989, 89, 1225. doi:10.1021/ cr00095a016.

(2) Morgan, K. M.; Ellis, J. A.; Lee, J.; Fulton, A.; Wilson, S. L.; Dupart, P. S.; Dastoori, R. J. Org. Chem. 2013, 78, 4303. doi:10.1021/jo4002867.

(3) Miranda, M. S.; Ferreira, P. J. O.; Esteves da Silva, J. C. G.; Liebman, J. F. Can. J. Chem. 2015, 93, 406. doi:10.1139/cjc-2014-0321.

(4) Curtiss, L. A.; Redfern, P. C.; Raghavachari, K. J. Chem. Phys. 2007, 126, 084108. doi:10.1063/1.2436888. The differences between the G4 and the previous G3 method are detailed in this reference. The G4 method was assessed using the 454 experimental energies in the G3/05 test set and the average absolute deviation from experiment showed an improvement from $1.13 \mathrm{kcal} \mathrm{mol}^{-1}$ (G3 method) to $0.83 \mathrm{kcal} \mathrm{mol}^{-1}$ (G4 method).

(5) Bader, R. F. W. Atoms in Molecules. A Quantum Theory; Clarendon: Oxford, UK, 1990.

(6) Popelier, P. Atoms in Molecules: An Introduction; Prentice-Hall: Manchester, UK, 2000.

(7) Matta, C. F.; Boyd, R. J. The Quantum Theory of Atoms in Molecules: From Solid State to DNA and Drug Design; Wiley-VCH: Weinheim, Germany, 2007.

(8) Becke, A. D. J. Chem. Phys. 1993, 98, 5648. doi:10.1063/1.464913.

(9) Stephens, P. J.; Devlin, F. J.; Chabalowski, C. F.; Frisch, M. J. J. Phys. Chem. 1994, 98, 11623. doi:10.1021/j100096a001.

(10) Frisch, M. J.; Trucks, G. W.; Schlegel, H. B.; Scuseria, G. E.; Robb, M. A.; Cheeseman, J. R.; Scalmani, G.; Barone, V.; Mennucci, B.; Petersson, G. A.; Nakatsuji, H.; Caricato, M.; Li, X.; Hratchian, H. P.; Izmaylov, A. F.; Bloino, J.; Zheng, G.; Sonnenberg, J. L.; Hada, M.; Ehara, M.; Toyota, K.; Fukuda, R.; Hasegawa, J.; Ishida, M.; Nakajima, T.; Honda, Y.; Kitao, O.; Nakai, H.; Vreven, T.; Montgomery, Jr., J. A.; Peralta, J. E.; Ogliaro, F.; Bearpark, M.; Heyd, J. J.; Brothers, E.; Kudin, K. N.; Staroverov, V. N.; Kobayashi, R.; Normand, J.; Raghavachari, K.; Rendell, A.; Burant, J. C.; Iyengar, S. S.; Tomasi, J.; Cossi, M.; Rega, N.; Millam, J. M.; Klene, M.; Knox, J. E.; Cross, J. B.; Bakken, V: Adamo, C; Jaramillo, J; Gomperts, R; Stratmann, R. E. Yazyev, O.; Austin, A. J.; Cammi, R.; Pomelli, C.; Ochterski, J. W.; Martin, R. L.; Morokuma, K.; Zakrzewski, V. G.; Voth, G. A.; Salvador, P.; Dannenberg, J. J.; Dapprich, S.; Daniels, A. D.; Farkas, O.; Foresman, J. B.;
Ortiz, J. V.; Cioslowski, J.; Fox, D. J. Gaussian 09, Revision A.02; Gaussian, Inc.: Wallingford, CT, 2009.

(11) Keith, T. A. AIMAll, Version 11.12.19; TK Gristmill Software: Overland Park, KS, 2011; Available from aim.tkgristmill.com.

(12) Symons, M. C. R. J. Am. Chem. Soc. 1980, 102, 3982. doi:10.1021/ja00531a067, 10.1021/ja00531a066.

(13) Lien, M. H.; Hopkinson, A. C. J. Org. Chem. 1988, 53, 2150. doi:10.1021/ jo00245a003.

(14) Lien, M. H.; Hopkinson, A. C. J. Am. Chem. Soc. 1988, 110, 3788. doi:10.1021/ ja00220a011.

(15) Lengyel, I.; Cesare, V.; Taldone, T. Tetrahedron 2004, 60, 1107. doi:10.1016/j. tet.2003.11.067.

(16) Yalcin, T.; Khouw, C.; Csizmadia, I. G.; Peterson, M. R.; Harrison, A. G. J. Am. Soc. Mass Spectrom. 1995, 6, 1165. doi:10.1016/1044-0305(95)00569-2.

(17) Harrison, A. G. Mass Spectrom. Rev. 2009, 28, 640. doi:10.1002/mas.20228.

(18) Greenberg, A.; Chiu, Y.-Y.; Johnson, J. L.; Liebman, J. F. Struct. Chem. 1991, 2, 117. doi:10.1007/BF00676622.

(19) Greenberg, A.; Hsing, H.-J.; Liebman, J. F. J. Mol. Struct.: THEOCHEM 1995, 338, 83. doi:10.1016/0166-1280(94)04050-3.

(20) Morgan, J.; Greenberg, A.; Liebman, J. F. Struct. Chem. 2012, 23, 197. doi:10. 1007/s11224-011-9851-7.

(21) Morgan, J.; Greenberg, A. J. Phys. Org. Chem. 2012, 25, 1422. doi:10.1002/poc. 3030.

(22) Ruttink, P. J. A.; Burgers, P. C.; Fell, L. M.; Terlouw, J. K. J. Phys. Chem. A 1999, 103, 1426. doi:10.1021/jp984015j.

(23) Ciuhandu, G.; Dumitreanu, A. J. Prakt. Chem. 1981, 323, 595. doi:10.1002/prac. 19813230410

(24) Olah, G. A.; Denis, J. M.; Westerman, P. W. J. Org. Chem. 1974, 39, 1206. doi:10.1021/jo00923a009.

(25) Hunter, E. P. L.; Lias, S. G. J. Phys. Chem. Ref. Data 1998, 27, 413. doi:10.1063/1. 556018.

(26) Hiraoka, K.; Shoda, T.; Morise, K.; Yamabe, S.; Kawai, E.; Hirao, K. J. Chem. Phys. 1986, 84, 2091. doi:10.1063/1.450418.

(27) Duarte, D. J. R.; Miranda, M. S.; Esteves da Silva, J. C. G. Struct. Chem. 2015, 26, 565. doi:10.1007/s11224-014-0519-y.

(28) Bader, R. F. W.; Gillespie, R. J.; MacDougall, P. J. J. Am. Chem. Soc. 1988, 110, 7329. doi:10.1021/ja00230a009. 